\title{
Cooling of Tree Surface Area due to Solar Reflective Coatings
}

\author{
David W. Yarbrough* \\ R\&D Engineering, LLC Watertown, USA
}

Submission: October 28, 2020; Published: November 04, 2020

"Corresponding author: David W. Yarbrough, R\&D Engineering, LLC Watertown, TN, 37184, USA

Keywords: Solar reflective coatings; Solar radiation; Solar flux; Cool coatings

Abbreviations: h, $h_{c}$ : Heat Transfer Coefficient W/m²; I: Solar Flux W $/ \mathrm{m}^{2} ; \mathrm{Q}_{\mathrm{soL}}$ : Product of $I$ and $\alpha \mathrm{W} / \mathrm{m}^{2} ; \mathrm{r}$ : Solar Reflectance; T: Temperature; $\alpha$ : Solar Absorptance; $\varepsilon$ : Thermal Emittance; $\sigma$ : Stefan-Boltzmann Constant $5.67 \times 10^{-8} \mathrm{~W} / \mathrm{m}^{2} \cdot \mathrm{K}^{4}$

\section{Introduction}

The application of a high solar reflectance coating to tree trunk surface area reduces the temperature of the surface when exposed to heat input from the sun. Solar reflectance $(r)$ of a surface is a number between 0 and 1 that quantifies the fraction of incoming solar radiation that is reflected by a surface. The solar absorptance $(\alpha)$ is the fraction of solar radiation that is absorbed by the surface. The solar absorptance is $1-r$. Coatings with solar reflectance's above 0.8 are often referred to as "cool coatings". The $\alpha$ value foe cool coating is generally less than 0.2 . High solar reflectance, cool, coatings have found use is reducing the maximum day-time temperature of roofs (cool-roof coatings). The same technology has potential use for the reduction of maximum daytime temperature of tree-surface area. A reduction of maximum tree surface temperatures contributes to the long-term health of the tree.

\section{Heat Balance to Calculate Temperatures}

The surface temperature of a surface exposed to solar radiation, $I$, can be calculated from a heat balance as shown in the ASTM Standard Practice E 1980 [1]. The heat balance as shown by the following equation includes the input of heat due to solar radiation $(\alpha \cdot I)$, thermal radiation exchange between the tree surface and the sky $\left(\varepsilon \cdot \sigma \cdot\left(T_{s}^{4}-T_{S K Y}{ }^{4}\right)\right)$, and heat exchange by conduction and convection between the tree surface and the surrounding air $\left(h_{C} \cdot\left(T_{S}-T_{A I R}\right)\right)$.

Since radiative transport is involved, the temperatures are expressed on the absolute or Kelvin scale (K).

$0=\alpha \cdot I-\varepsilon \cdot \sigma \cdot\left(T_{S}^{4}-T_{S K Y}{ }^{4}\right)-h_{C} \cdot\left(T_{S}-T_{A I R}\right)$
All of the terms in Equation are specified except $\mathrm{T}_{\mathrm{S}}$, the tree surface temperature on the Kelvin scale. $\mathrm{T}\left({ }^{\circ} \mathrm{F}\right)$ is obtained from $\mathrm{T}(\mathrm{K})$ by Equation 2.

$$
T\left({ }^{\circ} F\right)=(T(K)-273.15) \cdot 1.8+32
$$

$\mathrm{T}_{\mathrm{S}}$ is the "unknown" in Equation 1. The values for $\mathrm{T}_{\mathrm{S}}$ that satisfy Equation 1 can be determined numerically by assigning trial values for $\mathrm{T}_{\mathrm{S}}$ until the right side of Equation 1 equals zero. The $\mathrm{T}_{\mathrm{S}}$ values depend on the numerical values of all of the other terms in the equation. The values selected for the terms in Equation 1 are shown in Table 1. The values selected are guided by the discussion in $\mathrm{E} 1980$. The combination $\alpha \cdot I$ will be shown as $Q_{\mathrm{SoL}}$ to signify heat input from the sun in $W / \mathrm{m}^{2}$. The wind speeds shown in the $h_{c}$ line are approximations.

Table 1: Input for Equation 1.

\begin{tabular}{|c|c|c|}
\hline Term & Units & Values \\
\hline $\mathrm{Q}_{\mathrm{SOL}}$ & $\mathrm{W} / \mathrm{m}^{2}$ & 0 to 90 \\
\hline$\varepsilon$ & none & 0.9 (for tree surface and coating) \\
\hline$\sigma$ & $\mathrm{W} / \mathrm{m}^{2} \cdot \mathrm{K}^{4}$ & $5.67 \times 10^{-8}$ \\
\hline $\mathrm{T}_{\mathrm{SKY}}$ & $\mathrm{K}$ & $300\left(80.3^{\circ} \mathrm{F}\right)$ \\
\hline $\mathrm{h}_{\mathrm{C}}$ & $\mathrm{W} / \mathrm{m}^{2} \cdot \mathrm{K}$ & $5(\sim 2 \mathrm{mph})$ and $17(\sim 38 \mathrm{mph})$ \\
\hline
\end{tabular}

\section{Results for Tree-Surface Temperatures}

Table 2 contains surface temperature, $\mathrm{T}_{S}$, that satisfy Equation 1. for the listed $T_{A I R}, Q_{S O L}, \varepsilon$ and $h_{C}$ values. The smaller $h_{c}$ value (5) represents very little air movement. An increase in air speed to attain $\mathrm{h}_{\mathrm{C}} 17$ results in significant cooling of the tree surface $(212.5$ to 160.9 , for example). 


\section{Engineering Technology Open Access Journal}

Table 2: Estimate Maximum Surface Temperatures $\left({ }^{\circ} \mathrm{F}\right)$.

\begin{tabular}{|c|c|c|c|c|}
\hline \multirow{2}{*}{$\mathbf{Q}_{\text {SOL }}$} & \multicolumn{2}{|c|}{$\mathbf{T}_{\text {AIR }} \mathbf{9 8 . 3}$} & \multicolumn{2}{c|}{$\mathbf{T}_{\text {AIR }} \mathbf{8 0 . 3}$} \\
\cline { 2 - 5 } & $\mathbf{h}_{\mathbf{c}} \mathbf{5}$ & $\mathbf{h}_{\mathbf{C}} \mathbf{1 7}$ & $\mathbf{h}_{\mathbf{C}} \mathbf{5}$ & $\mathbf{h}_{\mathbf{C}} \mathbf{1 7}$ \\
\hline 900 & 212.5 & 160.9 & 207.6 & 148.8 \\
\hline 800 & 201.8 & 153.5 & 195.6 & 141.9 \\
\hline 700 & 189.0 & 146.9 & 183.3 & 134.5 \\
\hline 600 & 177.3 & 139.3 & 170.4 & 127.1 \\
\hline 500 & 163.5 & 131.8 & 156.9 & 119.6 \\
\hline 400 & 149.2 & 124.5 & 142.7 & 111.9 \\
\hline 300 & 135.9 & 117.2 & 127.7 & 104.2 \\
\hline 200 & 120.6 & 109.5 & 113.5 & 96.4 \\
\hline 100 & 104.6 & 101.7 & 97.6 & 88.5 \\
\hline 0 & 88.2 & 93.9 & 80.6 & 80.5 \\
\hline
\end{tabular}

Table 3 contains the results of subtracting $\mathrm{T}_{\mathrm{AIR}}$ from each of the entries in Table 2. The results show that the air speed (indicated by the increase in $h_{c}$ ) has a major impact on the tree surface temperature (cooling effect of the moving air). The entries above $\mathrm{Q}_{\mathrm{SOL}}=100$ shows that temperatures for a coating with high $\mathrm{r}$ $(r=0.9)$ and high solar flux (1000). The tree surface temperature is close to the air temperature even though the solar flux is very high. The negative values occurring at night $\left(Q_{\text {SoL }}=0\right)$ represent cooling by radiation to the night sky. The temperatures in Table 3 are ${ }^{\circ} \mathrm{F}$.
Table 3: Tree Surface Temperatures Exceed the Air Temperature.

\begin{tabular}{|c|c|c|c|c|}
\hline \multirow{2}{*}{$\mathbf{Q}_{\text {SOL }}$} & \multicolumn{2}{|c}{$\mathbf{T}_{\text {AIR }} \mathbf{9 8 . 3}$} & \multicolumn{2}{c|}{$\mathbf{T}_{\text {AIR }} \mathbf{8 0 . 3}$} \\
& $\mathbf{h}_{\mathbf{c}} \mathbf{5}$ & $\mathbf{h}_{\mathbf{c}} \mathbf{1 7}$ & $\mathbf{h}_{\mathbf{c}} \mathbf{5}$ & $\mathbf{h}_{\mathbf{C}} \mathbf{1 7}$ \\
\hline 900 & 114.2 & 62.6 & 127.3 & 68.5 \\
\hline 800 & 103.5 & 55.2 & 115.3 & 61.6 \\
\hline 700 & 90.7 & 48.6 & 103 & 54.2 \\
\hline 600 & 79.0 & 41.0 & 90.1 & 46.8 \\
\hline 500 & 65.2 & 33.5 & 76.6 & 39.3 \\
\hline 400 & 50.9 & 26.2 & 62.4 & 31.6 \\
\hline 300 & 37.6 & 18.9 & 47.4 & 23.9 \\
\hline 200 & 22.3 & 11.2 & 33.2 & 16.1 \\
\hline 100 & 6.3 & 3.4 & 17.3 & 8.2 \\
\hline 0 & -10.1 & -4.4 & 0.3 & 0.2 \\
\hline
\end{tabular}

Table 4 contains temperature reductions due to changing the solar absorptance (a) from 0.9 to either $\mathrm{a}=0.1$ or $\mathrm{a}=0.2$. These results are based on equations that are derived from the data shown in Table 2 and Figure 1.

Tsur $=94.153+0.1349 \cdot$ Qsol for Tair $=98.3$ and $h=5$

Tsur $=86.271+0.1375 . Q$ sol for Tair $=80.3$ and $h=17$

Tsur $=94.820+0.0738 . Q$ sol for Tair $=98.3$ and $h=5$

Tsur $=81.449+0.0755 \cdot Q$ sol for Tair $=80.3$ and $h=17$

Table 4: Reduction of Surface Temperature due to Coating ( $\left.{ }^{\circ} \mathrm{F}\right)$.

\begin{tabular}{|c|c|c|c|c|}
\hline Solar Flux & $\mathrm{a}=0.1 \mathrm{~T}$ reduction & $\mathrm{a}=0.2 \mathrm{~T}$ reduction & Condition & \\
\hline 700 & 71.4 & 66.1 & \multirow{5}{*}{ Tair $=98.3$} & \multirow{5}{*}{$\mathrm{h}=5$} \\
\hline 600 & 60.6 & 56.7 & & \\
\hline 500 & 49.8 & 47.2 & & \\
\hline 400 & 39.0 & 37.8 & & \\
\hline 300 & 38.2 & 28.3 & & \\
\hline 700 & 41.3 & 36.2 & \multirow{5}{*}{ Tair $=98.5$} & \multirow{5}{*}{$\mathrm{h}=17$} \\
\hline 600 & 35.4 & 31.0 & & \\
\hline 500 & 29.5 & 25.8 & & \\
\hline 400 & 23.6 & 20.7 & & \\
\hline 300 & 17.7 & 15.5 & & \\
\hline 700 & 72.9 & 67.7 & \multirow{5}{*}{ Tair $=80.3$} & \multirow{5}{*}{$\mathrm{h}=5$} \\
\hline 600 & 61.3 & 56.8 & & \\
\hline 500 & 49.6 & 46.0 & & \\
\hline 400 & 38.0 & 35.0 & & \\
\hline 300 & 26.4 & 24.1 & & \\
\hline 700 & 42.3 & 37.0 & \multirow{5}{*}{ Tair $=80.3$} & \multirow{5}{*}{$\mathrm{h}=17$} \\
\hline 600 & 36.2 & 31.7 & & \\
\hline 500 & 30.2 & 26.4 & & \\
\hline 400 & 24.2 & 21.1 & & \\
\hline 300 & 18.1 & 15.9 & & \\
\hline
\end{tabular}




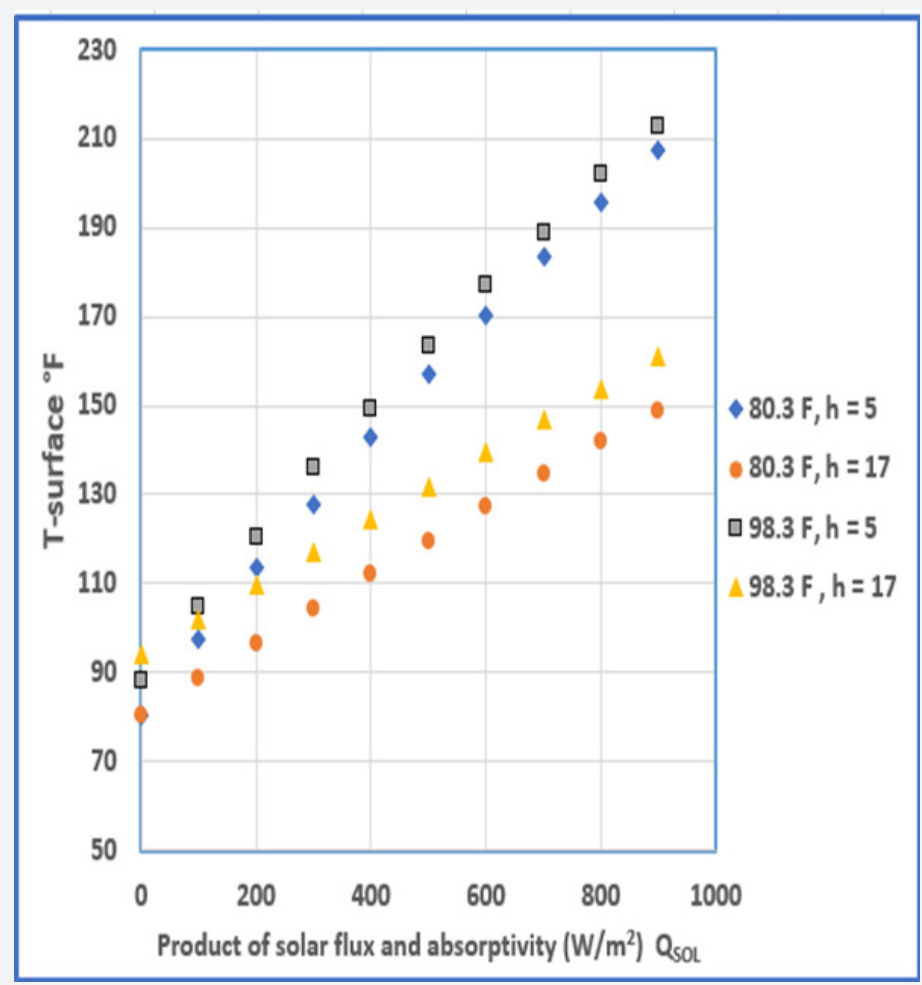

Figure 1: Maximum Surface Temperatures from Table 2 (Air temperatures in ${ }^{\circ} \mathrm{F}$ and $\mathrm{h}$ in $\mathrm{W} / \mathrm{m} 2$ ).

The temperature reductions due to coating in Table 4 are in ${ }^{\circ} \mathrm{F}$. The uncoated surface is assigned a solar absorption of 0.9 . Two values for the solar absorption of coated surface were evaluated to show the range anticipated for the temperature reduction due to coating.

Figure 1 contains the surface temperatures for the four cases that were considered. The graphical results show the distinct division for the two heat transfer coefficients ( $h$ or $h_{c}$ ) for which results were calculated. The Surface temperatures are directly proportional to the absorbed solar radiation when the other terms remain constant.

\section{Discussion}

The calculations presented here do not include heat conducted to the interior of the tree or the cooling effect of evaporation. Bark temperature of $130^{\circ} \mathrm{F}$ have been reported for wild cherry trees by Sheppard et al. [2] for air temperatures in the range considered here but unknown solar flux. The $130^{\circ} \mathrm{F}$ observation corresponds to the current results with solar flux of $\sim 500 \mathrm{~W} / \mathrm{m}^{2}$ and $\mathrm{r}=0.2$. The high temperatures obtained in the present calculation result from severe conditions: high solar flux and very little wind.

\section{References}

1. ASTM E (1980) Standard Practice for Calculating Solar Reflectance Index of Horizontal and Low-Slope Opaque Surfaces. Annual Book of ASTM Standards, 04.06.

2. Sheppard J, Morhart C, Spieckler H (2016) Bark surface temperature measurements on the boles of wild cherry (Prunus avium) grown within an agroforestry system. Silva Fennica 50(3). 
Your next submission with Juniper Publishers will reach you the below assets

- Quality Editorial service

- Swift Peer Review

- Reprints availability

- E-prints Service

- Manuscript Podcast for convenient understanding

- Global attainment for your research

- Manuscript accessibility in different formats ( Pdf, E-pub, Full Text, Audio)

- Unceasing customer service

Track the below URL for one-step submission https://juniperpublishers.com/online-submission.php 